\title{
ETNOBOTANI TUMBUHAN DALAM MAKANAN TRADISIONAL PECEL DI DESA SUMBERMULYO KECAMATAN JOGOROTO KABUPATEN JOMBANG JAWA TIMUR
}

\author{
Mucharommah Sartika Ami, Evi Ayu Candra \\ Fakultas Ilmu Pendidikan, Universitas KH. A. Wahab Hasbullah \\ Correspondence Author: sartika.ami@gmail.com
}

\begin{tabular}{|c|c|}
\hline Info Artikel : & ABSTRACT \\
\hline \multirow[t]{2}{*}{$\begin{array}{l}\text { Sejarah Artikel : } \\
\text { Menerima : } 13 \text { Juni } \\
\text { Revisi : 28 Juni } \\
\text { Diterima : 29 Juli } \\
\text { Online : 01 Agustus } \\
\text { Keyword : } \\
\text { Ethnobotany, } \\
\text { traditional food, } \\
\text { Pecel. }\end{array}$} & $\begin{array}{l}\text { Plants cannot be separated from everyday human life, including in terms of } \\
\text { meeting food needs. Interactions between humans and plants were studied in } \\
\text { ethnobotany. This study aims to determine the types and parts of plants used } \\
\text { in traditional cuisine Pecel in the village Sumbermulyo sub-district Jogoroto, } \\
\text { Jombang, East Java. The methods used were interviews and direct } \\
\text { observation. The interview method was conducted in a semi-structured } \\
\text { manner with the respondents determined through purposive random } \\
\text { sampling technique. Direct observation was carried out to identify the types } \\
\text { and parts of plants used in traditional food Pecel based on the results of the } \\
\text { interview. The data obtained were then analyzed descriptively. The results } \\
\text { showed that there were } 16 \text { plants species used in traditional food Pecel in } \\
\text { Sumbermulyo village. Various plants, among others Allium sativum, } \\
\text { Capsicum anuum, Capsicum frutescens, Citrus hystrix, Vigna radiata, Vigna } \\
\text { sinensis, Arachis hypogaea, Ipomoea reptans, Cocos nucifera, Ocimum } \\
\text { sanctum, Cucumis sativus var krai, Cucumis sativus, Oryza sativa, Carica } \\
\text { papaya, Musa sp., dan Sesbania grandiflora. Plant parts used were buds, } \\
\text { stems, leaves, flowers, fruits, seeds, and bulbs. }\end{array}$ \\
\hline & \\
\hline $\begin{array}{l}\text { Kata Kunci : } \\
\text { etnobotani, } \\
\text { makanan } \\
\text { tradisional, Pecel. }\end{array}$ & $\begin{array}{l}\text { Tumbuhan tidak dapat dipisahkan dari kehidupan manusia sehari-hari, } \\
\text { termasuk dalam hal memenuhi kebutuhan makanan. Interaksi antara } \\
\text { manusia dan tumbuhan dipelajari dalam studi etnobotani. Penelitian ini } \\
\text { bertujuan untuk mengetahui jenis-jenis dan bagian-bagian tumbuhan yang } \\
\text { digunakan dalam makanan tradisional Pecel yang ada di Desa Sumbermulyo } \\
\text { Kecamatan Jogoroto Kabupaten Jombang Jawa Timur. Metode yang } \\
\text { digunakan adalah wawancara dan observasi langsung. Metode wawancara } \\
\text { dilakukan secara semi terstruktur dengan responden yang ditentukan melalui } \\
\text { teknik pengambilan sampel acak terpilih. Observasi langsung dilakukan } \\
\text { untuk mengidentifikasi jenis dan bagian tumbuhan yang digunakan dalam } \\
\text { makanan tradisional Pecel berdasarkan hasil wawancara. Data-data yang } \\
\text { diperoleh selanjutnya dianalisis secara deskriptif. Hasil penelitian }\end{array}$ \\
\hline
\end{tabular}




\begin{tabular}{|l|l|}
\hline menunjukkan ada 16 jenis tumbuhan yang digunakan dalam makanan \\
tradisional Pecel di Desa Sumbermulyo. Berbagai tumbuhan tersebut antara \\
lain: Allium sativum, Capsicum anuum, Capsicum frutescens, Citrus hystrix, \\
Vigna radiata, Vigna sinensis, Arachis hypogaea, Ipomoea reptans, Cocos \\
nucifera, Ocimum sanctum, Cucumis sativus var krai, Cucumis sativus, \\
$\begin{array}{l}\text { Oryza sativa, Carica papaya, Musa sp., dan Sesbania grandiflora. Bagian- } \\
\text { bagian tumbuhan yang digunakan adalah tunas, batang, daun, bunga, buah, } \\
\text { biji, dan umbi. }\end{array}$ \\
\hline
\end{tabular}

\section{PENDAHULUAN}

Manusia telah lama memanfaatkan berbagai jenis tumbuhan untuk memenuhi kebutuhan hidupnya, termasuk kebutuhan makan. Masyarakat Indonesia yang multikultural memiliki berbagai jenis makanan tradisional yang sebagian besar bahan bakunya berasal dari tumbuhan. Salah satu makanan tradisional yang masih sering dijumpai adalah Pecel. Menu makanan tradisional ini termasuk menu vegetarian karena berisi aneka jenis sayuran yang direbus atau segar dan dikonsumsi bersama saus kacang serta rempeyek. Saus kacang dan rempeyek sebagai pelengkap sajian Pecel pun menggunakan aneka tumbuhan rempah sebagai bumbunya. Keanekaragaman jenis tumbuhan yang digunakan dalam Pecel merupakan obyek kajian etnobotani. Etnobotani mempelajari keragaman tumbuhan dan pemanfaatannya oleh masyarakat lokal (Apriliani et al. 2014).

Desa Sumbermulyo di Kecamatan Jogoroto Kabupaten Jombang Provinsi Jawa Timur merupakan sentra pedagang Pecel. Observasi yang dilakukan oleh peneliti di desa ini pada bulan April 2019 menunjukkan bahwa terdapat 100 orang warga desa yang berdagang Pecel. Kajian etnobotani tumbuhan yang digunakan dalam makanan tradisional Pecel belum pernah dilakukan, terlebih di Desa Sumbermulyo tersebut. Kajian ini diperlukan sebagai tambahan informasi taksonomi tumbuhan berbasis kearifan lokal yang dapat digunakan sebagai sumber belajar mahasiswa maupun masyarakat lainnya. Informasi ini dapat pula digunakan sebagai upaya konservasi lingkungan sekaligus konservasi budaya di tengah resiko kerusakan akibat modernisasi (Silalahi et al. 2018). Oleh karena itu, penelitian ini dilakukan dengan tujuan untuk mengetahui jenis-jenis dan bagian-bagian tumbuhan yang digunakan oleh masyarakat Desa Sumbermulyo Kecamatan Jogoroto Kabupaten Jombang Jawa Timur dalam menu makanan tradisional Pecel.

\section{METODE PENELITIAN}

Penelitian ini dilakukan pada bulan April hingga Juni 2019 di Desa Sumbermulyo Kecamatan Jogoroto Kabupaten Jombang Provinsi Jawa Timur. Metode yang digunakan adalah wawancara dengan responden yang dipilih secara acak terpilih (purposive random sampling) dan observasi langsung. Metode wawancara dilakukan secara semi terstruktur kepada 20 responden yang merupakan pedagang Pecel di Desa Sumbermulyo, dengan menggunakan panduan wawancara. Wawancara ini dilakukan untuk memperoleh data mengenai nama-nama lokal tumbuhan yang digunakan dalam makanan tradisional Pecel. Data yang diperoleh dari hasil wawancara digunakan sebagai panduan dalam melakukan observasi langsung. Kegiatan observasi langsung dilakukan untuk mengetahui struktur morfologi jenis dan bagian tumbuhan yang digunakan dalam makanan tradisional Pecel. Instrumen yang digunakan dalam observasi langsung adalah lembar observasi. Hasil observasi ini selanjutnya dikoreksi melalui studi pustaka untuk 
mengetahui nama ilmiah tumbuhan menurut taksonomi tumbuhan. Data penelitian yang telah dikumpulkan dianalisis secara deskriptif.

\section{HASIL DAN ANALISA}

Hasil wawancara menunjukkan ada 16 jenis tumbuhan yang digunakan oleh masyarakat Desa Sumbermulyo dalam pembuatan makanan tradisional Pecel. Jenis-jenis tumbuhan tersebut selanjutnya diobservasi secara langsung struktur morfologinya untuk mengidentifikasi nama ilmiahnya menurut ilmu taksonomi tumbuhan. Tabel 1 menunjukkan ringkasan hasil wawancara dan observasi langsung yang telah dilakukan.

Tabel 1. Tumbuhan yang Digunakan dalam Makanan Tradisional Pecel di Desa Sumbermulyo Kecamatan Jogoroto Kabupaten Jombang Jawa Timur

\begin{tabular}{|c|c|c|c|c|}
\hline No. & Nama Lokal & Nama Ilmiah & Struktur Morfologi & $\begin{array}{c}\text { Bagian yang } \\
\text { Digunakan }\end{array}$ \\
\hline 1 & Bawang putih & Allium sativum & $\begin{array}{l}\text { Akar serabut; batang berbentuk } \\
\text { cakram di bagian pangkal dan } \\
\text { membentuk umbi yang menggembung } \\
\text { di bagian ujung dan berwarna putih; } \\
\text { daun tunggal, terdiri dari helai daun } \\
\text { dan pelepah yang menempel pada } \\
\text { ujung batang secara rapat hingga } \\
\text { membentuk batang semu, helai daun } \\
\text { berbentuk pita pipih, bertulang sejajar, } \\
\text { tepi rata, dan ujung runcing; bunga } \\
\text { berbentuk bulat, berwarna putih } \\
\text { kemerahan, tumbuh pada ujung } \\
\text { batang, bersifat hemafrodit, dan jarang } \\
\text { terbentuk. }\end{array}$ & Umbi \\
\hline 2 & Cabai merah & $\begin{array}{l}\text { Capsicum } \\
\text { anuum }\end{array}$ & $\begin{array}{l}\text { Akar tunggang; batang bercabang, } \\
\text { berwarna hijau; daun tunggal terdiri } \\
\text { dari helai daun dan tangkai yang } \\
\text { menempel pada cabang secara } \\
\text { berseling, helai daun berbentuk jorong, } \\
\text { bertulang menyirip, pangkal runcing, } \\
\text { tepi rata, ujung runcing; bunga } \\
\text { berbentuk bintang, berwarna putih, } \\
\text { tumbuh tunggal atau tandan di ketiak } \\
\text { daun, bersifat hemafrodit; buah } \\
\text { berbentuk lanset silindris, } \\
\text { menggantung, ujung runcing, } \\
\text { berdiameter 1-2 cm dengan panjang } \\
\text { sekitar } 15 \mathrm{~cm} \text {; biji berbentuk bulat } \\
\text { pipih, berwarna putih kekuningan, } \\
\text { berdiameter 3-5 mm. }\end{array}$ & Buah \\
\hline 3 & Cabai rawit & $\begin{array}{l}\text { Capsicum } \\
\text { frutescens }\end{array}$ & $\begin{array}{l}\text { Akar tunggang; batang bercabang, } \\
\text { berwarna hijau; daun tunggal terdiri }\end{array}$ & Buah \\
\hline
\end{tabular}




\begin{tabular}{|c|c|c|c|c|}
\hline No. & Nama Lokal & Nama Ilmiah & Struktur Morfologi & $\begin{array}{c}\text { Bagian yang } \\
\text { Digunakan }\end{array}$ \\
\hline 4 & Jeruk purut & Citrus hystrix & $\begin{array}{l}\text { dari helai daun dan tangkai yang } \\
\text { menempel pada cabang secara } \\
\text { berseling, helai daun berbentuk jorong, } \\
\text { bertulang menyirip, pangkal runcing, } \\
\text { tepi rata, ujung runcing; bunga } \\
\text { berbentuk bintang, berwarna putih } \\
\text { kekuningan, tumbuh tunggal atau } \\
\text { tandan di ketiak daun, bersifat } \\
\text { hemafrodit; buah berbentuk lanset } \\
\text { silindris, mendongak, ujung runcing, } \\
\text { berdiameter } 8 \text { mm dengan panjang } \\
\text { sekitar } 5 \text { cm; biji berbentuk bulat } \\
\text { pipih, berwarna putih kekuningan, } \\
\text { berdiameter 3-5 mm. } \\
\text { Akar tunggang; batang bercabang, } \\
\text { memiliki duri panjang pada } \\
\text { permukaannya; daun majemuk beranak } \\
\text { daun satu, terdiri dari helai daun dan } \\
\text { tangkai yang menempel pada cabang } \\
\text { secara berseling, helai daun berbentuk } \\
\text { bulat telur, bertulang menyirip, } \\
\text { pangkal tumpul, tepi beringgit, ujung } \\
\text { tumpul atau meruncing, permukaan } \\
\text { atas mengkilap, beraroma harum yang } \\
\text { khas saat diremas; bunga berbentuk } \\
\text { bintang, berwarna putih kemerahan } \\
\text { atau kekuningan, tumbuh pada ujung } \\
\text { cabang, bersifat hermafrodit; buah } \\
\text { berbentuk bulat, permukaan kasar } \\
\text { berbenjol; biji berbentuk bulat telur, } \\
\text { berwarna putih. }\end{array}$ & Daun \\
\hline 5 & Kacang hijau & Vigna radiata & $\begin{array}{l}\text { Akar tunggang; batang bercabang, } \\
\text { berwarna hijau, terdapat rambut halus } \\
\text { pada permukaannya; daun majemuk } \\
\text { beranak daun tiga, tangkai daun } \\
\text { menempel pada cabang secara } \\
\text { berseling, helai daun berbentuk jorong, } \\
\text { bertulang menyirip, pangkal runcing, } \\
\text { tepi rata, ujung runcing; bunga } \\
\text { berbentuk kupu-kupu, berwarna } \\
\text { kuning, tumbuh pada ketiak daun, } \\
\text { bersifat hemafrodit; buah berbentuk } \\
\text { polong dengan panjang 6-15 cm; biji } \\
\text { berbentuk bulat lonjong, berwarna } \\
\text { hijau, berjumlah 6-16 butir dalam }\end{array}$ & Tunas \\
\hline
\end{tabular}




\begin{tabular}{|c|c|c|c|c|}
\hline No. & Nama Lokal & Nama Ilmiah & Struktur Morfologi & $\begin{array}{c}\text { Bagian yang } \\
\text { Digunakan }\end{array}$ \\
\hline & & & setiap buah. & \\
\hline 6 & Kacang panjang & Vigna sinensis & $\begin{array}{l}\text { Akar tunggang; batang menjalar, } \\
\text { berwarna hijau; daun majemuk } \\
\text { beranak daun tiga, helai daun } \\
\text { berbentuk tombak, bertulang menyirip, } \\
\text { pangkal runcing, tepi rata, ujung } \\
\text { runcing, permukaan atas kasar; bunga } \\
\text { berbentuk kupu-kupu, berwarna } \\
\text { kuning, tumbuh pada lateral batang, } \\
\text { bersifat hemafrodit; buah berbentuk } \\
\text { gilig dengan panjang } 10-80 \mathrm{~cm} \text {; biji } \\
\text { berbentuk lonjong dengan panjang } 1 \\
\text { cm, warna bervariasi dari putih hingga } \\
\text { ungu. }\end{array}$ & Buah \\
\hline 7 & Kacang tanah & $\begin{array}{l}\text { Arachis } \\
\text { hypogaea }\end{array}$ & $\begin{array}{l}\text { Akar tunggang; batang bercabang, } \\
\text { memiliki rambut-rambut halus pada } \\
\text { permukaannya; daun majemuk beranak } \\
\text { daun empat, helai daun berbentuk } \\
\text { bulat telur, bertulang menyirip, } \\
\text { pangkal tumpul, tepi rata, ujung } \\
\text { tumpul; bunga berbentuk kupu-kupu, } \\
\text { berwarna kuning, tumbuh pada ketiak } \\
\text { daun, bersifat hemafrodit; buah } \\
\text { berbentuk polong, tumbuh di bawah } \\
\text { tanah, kulit beralur; biji berbentuk } \\
\text { bulat, berjumlah 1-5 dalam satu buah, } \\
\text { warna bervariasi dari putih hingga } \\
\text { merah. }\end{array}$ & Biji \\
\hline 8 & Kangkung & Ipomoea reptans & $\begin{array}{l}\text { Akar tunggang; batang basah, } \\
\text { berwarna hijau, berongga pada bagian } \\
\text { ruasnya; daun tunggal dengan tangkai } \\
\text { menempel pada buku batang } \\
\text { berhadapan, helai daun berbentuk } \\
\text { lanset, bertulang menyirip, pangkal } \\
\text { tumpul, tepi rata, ujung runcing; bunga } \\
\text { berbentuk terompet, berwarna putih } \\
\text { hingga merah muda, tumbuh pada } \\
\text { ketiak daun, bersifat hemafrodit; buah } \\
\text { berbentuk bulat telur; biji berbentuk } \\
\text { bulat cenderung bersegi, berwarna } \\
\text { cokelat, berjumlah } 3 \text { dalam setiap } \\
\text { buah. }\end{array}$ & $\begin{array}{l}\text { Daun dan } \\
\text { batang }\end{array}$ \\
\hline 9 & Kelapa & Cocos nucifera & $\begin{array}{l}\text { Akar serabut; batang tidak bercabang, } \\
\text { berkayu, bekas tangkai daun terlihat }\end{array}$ & Bunga (nira) \\
\hline
\end{tabular}




\begin{tabular}{|c|c|c|c|c|}
\hline No. & Nama Lokal & Nama Ilmiah & Struktur Morfologi & $\begin{array}{c}\text { Bagian yang } \\
\text { Digunakan }\end{array}$ \\
\hline & & & $\begin{array}{l}\text { jelas di permukaannya; daun majemuk } \\
\text { menyirip membentuk roset batang, } \\
\text { anak daun dapat mencapai } 120 \text { buah, } \\
\text { helai daun berbentuk lanset, bertulang } \\
\text { sejajar dengan ibu tulang tampak jelas, } \\
\text { pangkal tumpul, tepi rata, ujung } \\
\text { runcing; bunga majemuk, terpisah } \\
\text { antara bunga jantan dan betina namun } \\
\text { masih dalam satu pohon, tumbuh pada } \\
\text { ketiak daun; buah berbentuk bulat, } \\
\text { terdiri dari tiga lapisan (eksokarp, } \\
\text { mesokarp, dan endokarp), warna } \\
\text { tergantung varietas; biji terletak di } \\
\text { sebelah dalam endokarp dengan } \\
\text { endosperma tebal dan embrio } \\
\text { berwarna putih. }\end{array}$ & \\
\hline 10 & Kemangi & $\begin{array}{l}\text { Ocimum } \\
\text { sanctum }\end{array}$ & $\begin{array}{l}\text { Akar tunggang; batang bercabang, } \\
\text { berwarna hijau; daun tunggal, tangkai } \\
\text { daun menempel pada cabang secara } \\
\text { berhadapan, helai daun berbentuk oval, } \\
\text { bertulang menyirip, pangkal } \\
\text { membulat, tepi rata, ujung meruncing, } \\
\text { beraroma harum yang khas saat } \\
\text { diremas; bunga majemuk, berwarna } \\
\text { putih, tumbuh pada ujung cabang, } \\
\text { bersifat hemafrodit; buah berbentuk } \\
\text { kotak, berwarna cokelat; biji berbentuk } \\
\text { bulat pipih, berwarna cokelat tua, } \\
\text { berjumlah empat dalam satu buah. }\end{array}$ & Daun \\
\hline 11 & Krai & $\begin{array}{l}\text { Cucumis sativus } \\
\text { var krai }\end{array}$ & $\begin{array}{l}\text { Akar tunggang; batang berbentuk } \\
\text { silindris dengan rambut-rambut halus } \\
\text { di permukaannya, bercabang dan } \\
\text { memiliki sulur; daun tunggal } \\
\text { berbentuk bulat berlekuk hingga } \\
\text { bercangap, bertulang menyirip, } \\
\text { pangkal berlekuk, tepi bergerigi, ujung } \\
\text { runcing, terdapat rambut-rambut halus } \\
\text { pada permukaannya; bunga berbentuk } \\
\text { terompet, berwarna kuning, tumbuh } \\
\text { pada ketiak daun, bersifat hemafrodit; } \\
\text { buah berbentuk bulat lonjong, } \\
\text { menggantung, permukaan halus } \\
\text { dengan warna hijau gelap bergaris } \\
\text { putih berselang-seling; biji berbentuk } \\
\text { oval dengan ujung runcing, berwarna }\end{array}$ & Buah \\
\hline
\end{tabular}




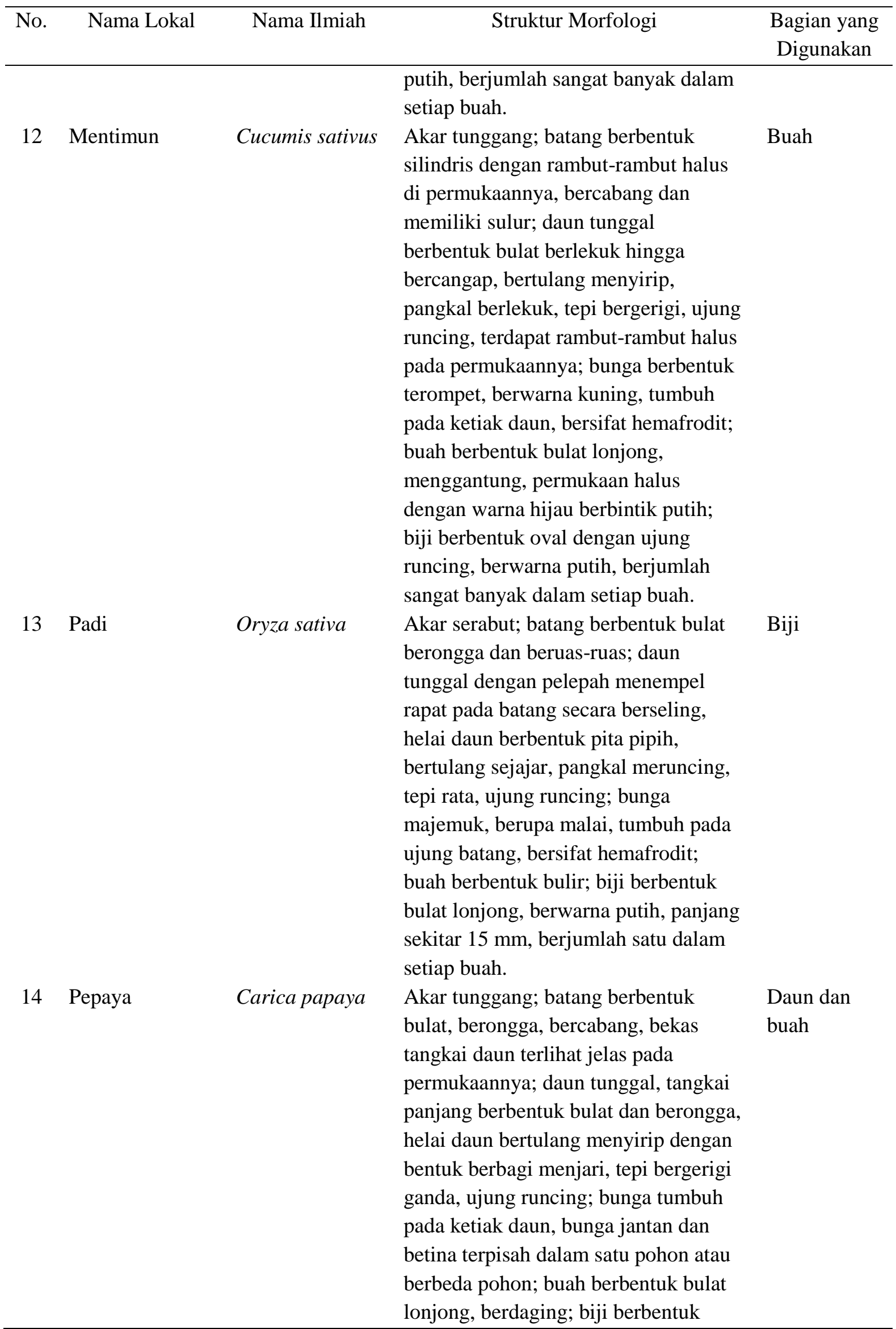




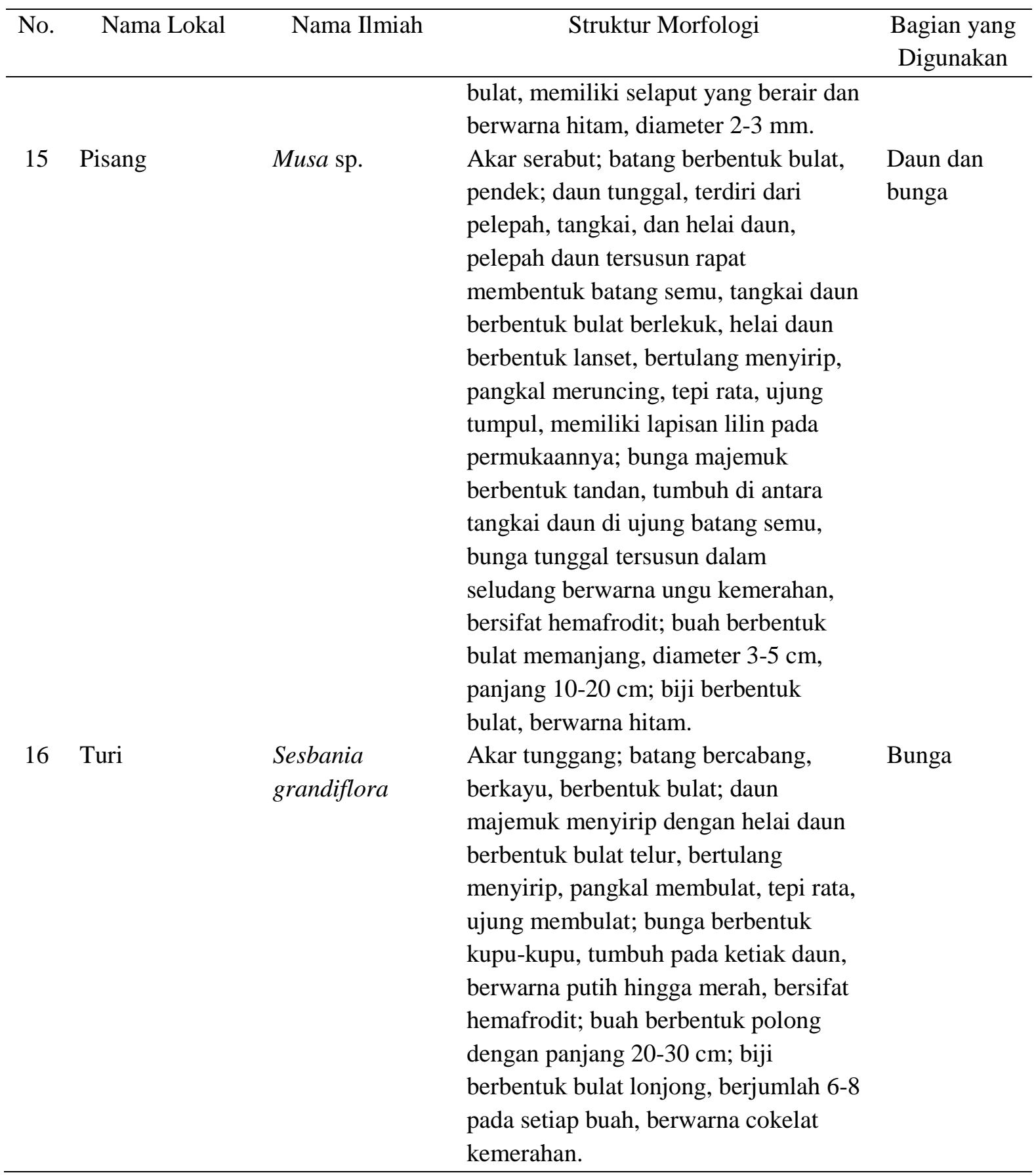

Umbi bawang putih, buah cabai merah, buah cabai rawit, dan daun jeruk purut digunakan sebagai bumbu dalam pembuatan saus kacang (sambal kacang) sebagai pelengkap sajian Pecel. Nira dari bunga jantan tumbuhan kelapa diolah menjadi gula merah, dan digunakan sebagai penyedap dalam pembuatan saus kacang tersebut. Biji kacang tanah digunakan sebagai bahan utama pembuatan saus kacang tersebut, dan digunakan pula sebagai isian rempeyek. Umbi bawang putih diketahui mengandung minyak atsiri dan senyawa allicin yang dapat melezatkan masakan dan juga berkhasiat obat (Salima 2015). Buah cabai merah dan cabai rawit mengandung minyak atsiri dan senyawa capsaicin yang memberikan rasa pedas pada masakan (Al-Snafi 2015). Buah cabai merah juga mengandung banyak karotenoid yang mampu memberikan warna merah pada masakan (Khan et al. 2014). Daun jeruk purut mengandung minyak atsiri sehingga menghasilkan aroma 
harum yang dapat menambah sedap masakan (Adrianto et al. 2014). Biji kacang tanah diketahui mengandung nutrisi yang baik, seperti lemak; protein; zat besi; vitamin A, B, E, dan K; kalsium; serta fosfor (Zulchi dan Puad 2017).

Varian sayuran yang digunakan sebagai komponen utama Pecel berupa: daun pepaya, buah pepaya muda, jantung pisang, buah mentimun, buah krai, tunas (kecambah) kacang hijau, buah kacang panjang, bunga turi, daun kemangi, daun dan batang kangkung. Buah mentimun dan daun kemangi dikonsumsi dalam bentuk segar, sedangkan jenis sayuran lainnya dikonsumsi setelah direbus. Daun pepaya memiliki rasa pahit karena kandungan enzim papain di dalamnya (Sudhakar dan Vidhya 2014), namun masyarakat di Desa Sumbermulyo mengolah daun pepaya ini dengan penambahan air kapur dan tanah liat sehingga mengurangi rasa pahitnya. Buah pepaya muda memiliki tekstur yang keras sehingga masyarakat mengiris tipis atau menyerutnya sebelum direbus, agar mudah dikonsumsi. Jantung pisang mengandung karbohidrat; protein; lemak; kalsium; fosfor; vitamin $\mathrm{A}, \mathrm{B}$, dan $\mathrm{C}$; serta serat yang tinggi untuk menjaga kesehatan saluran pencernaan (Novitasari et al. 2013). Buah mentimun banyak mengandung air sehingga cocok dikonsumsi dalam bentuk segar, selain itu juga mengandung antioksidan yang baik bagi kesehatan (Foong et al. 2015).

Buah krai merupakan varietas mentimun, dapat dibedakan dari morfologi buahnya, yaitu adanya garis putih yang tampak jelas di permukaannya. Buah krai biasanya direbus hingga menjadi bendoyo oleh masyarakat Jawa Timur, dapat dikonsumsi langsung atau disajikan dalam Pecel. Kecambah kacang hijau juga digunakan dalam Pecel. Tunas tumbuhan kacang hijau ini banyak mengandung vitamin E yang baik bagi kesehatan kulit dan reproduksi (Asrullah 2015). Buah kacang panjang yang masih muda berwarna hijau dan direbus sebagai salah satu komponen Pecel. Buah ini mengandung vitamin A, B, C; mineral; protein; lemak; dan karbohidrat (Simarmata et al. 2015). Bunga turi yang digunakan dalam Pecel ada dua macam, yaitu bunga turi merah dan putih. Bunga turi yang dipilih sebagai sayur oleh masyarakat adalah bunga yang masih kuncup. Bunga turi mengandung nutrisi penting seperti karbohidrat, protein, lemak, kalsium, magnesium, zat besi, fosfor, vitamin C, dan asam folat (Karmakar et al., 2016). Daun kemangi memiliki aroma yang khas karena adanya minyak atsiri dan metabolit sekunder lain yang bersifat antimikroba (Bhatt 2012). Kangkung merupakan sayuran hijau yang banyak dikonsumsi oleh masyarakat. Kangkung mengandung protein; lemak; karbohidrat; kalsium; zat besi; vitamin A, B, dan C (Wibowo dan Sitawati 2017).

\section{KESIMPULAN}

Terdapat 16 jenis tumbuhan yang digunakan oleh masyarakat Desa Sumbermulyo Kecamatan Jogoroto Kabupaten Jombang Provinsi Jawa Timur dalam pembuatan makanan tradisional Pecel. Sebanyak empat jenis merupakan Kelas Monocotyledonae dan 13 jenis lainnya merupakan Kelas Dicotyledonae. Bagian-bagian tumbuhan yang digunakan beragam, yaitu tunas, batang, daun, bunga, buah, biji, dan umbi. Hasil penelitian ini merupakan sumber informasi etnobotani yang dapat digunakan sebagai bahan penyusunan sumber belajar untuk mahasiswa, khususnya yang tengah menempuh matakuliah Taksonomi Tumbuhan.

\section{ACKNOWLEDGEMENTS}

Penelitian ini dibiayai oleh Direktorat Riset dan Pengabdian Masyarakat Kementerian Riset Teknologi dan Pendidikan Tinggi melalui skema Penelitian Dosen Pemula Tahun Anggaran 2019. 


\section{DAFTAR PUSTAKA}

Adrianto, H., Yotopranoto, S. dan Hamidah, 2014, Efektivitas Ekstrak Daun Jeruk Purut (Citrus hystrix), Jeruk Limau (Citrus amblycarpa), dan Jeruk Bali (Citrus maxima) terhadap Larva Aedes aegypti. Aspirator 6. 1-6.

Al-Snafi, A. E., 2015, The Pharmacological Importance of Capsicum Species (Capsicum anuum and Capsicum frutescens) Grown in Iraq. Journal of Pharmaceutical Biology 5. 124-142.

Apriliani, A., Sukarsa, dan Hidayah, H. A., 2014, Kajian Etnobotani Tumbuhan sebagai Bahan Tambahan Pangan secara Tradisional oleh Masyarakat di Kecamatan Pekuncen Kabupaten Banyumas. Scripta Biologica 1. 76-84.

Asrullah, M., 2015, Kecambah Kacang Hijau dan Efikasinya terhadap Kesehatan. BIMGI 3. 30-35.

Bhatt, K. J., 2012, Ocimum sanctum: The Indian Medicinal Plant. International Journal of Chemtech Application 3. 53-57.

Foong, F. H. N., Mohammad, A. dan Ichwan, S. J. A., 2015, Biological Properties of Cucumber (Cucumis sativus L.) Extracts. Malaysian Journal of Analytical Sciences 19. 1218-1222.

Karmakar, P., Singh, V., Yadava, R. B., Singh, B., Singh, R., dan Kushwaha, M., 2016, Agathi [Sesbania grandiflora L. (Agast)]: Current Status of Production, Protection and Genetic Improvement. National Symposium on Vegetable Legumes for Soil and Human Health. 153-161.

Khan, F. A., Mahmood, T., Ali, M., Saeed, A. dan Maalik, A., 2014, Pharmacological Importance of An Ethnobotanical Plant: Capsicum anuum L. Natural Product Research 28. 1267-1274.

Novitasari, A., Ambarwati, A., Lusia, A., Purnamasari, D., Hapsari, E., dan Ardiyani, N. D., 2013, Inovasi dari Jantung Pisang (Musa spp.). Jurnal Kesmadaska. 96-99.

Salima, J., 2015, Antibacterial Activity of Garlic (Allium sativum L.). J. Majority 4. 30-39.

Silalahi, M., Nisyawati, dan Anggraeni, R., 2018, Studi Etnobotani Tumbuhan Pangan yang Tidak Dibudidayakan oleh Masyarakat Lokal Sub-etnis Batak Toba, di Desa Peadungdung Sumatera Utara, Indonesia. Jurnal Pengelolaan Sumberdaya Alam dan Lingkungan 8. 241250.

Simarmata, E. R., Ardian, dan Sa'diyah, N., 2015, Penampilan Karakter Produksi Kacang Panjang (Vigna sinensis L.) Generasi F1 dan Tetuanya. J. Agrotek Tropika 3. 303-308.

Sudhakar, N. dan Vidhya, T., 2014, Potential Medicinal Properties of Carica papaya Linn. A Mini Review. International Journal of Pharmacy and Pharmaceutical Sciences 6. 1-4.

Wibowo, H. Y. dan Sitawati, 2017, Respon Tanaman Kangkung Darat (Ipomoea reptans Poir) dengan Interval Penyiraman pada Pipa Vertikal. Plantropica 2. 148-154.

Zulchi, T. dan Puad, H., 2017, Keragaman Morfologi dan Kandungan Protein Kacang Tanah (Arachis hypogaea L.). Bul. Plasma Nutfah, 23. 91-100. 